\title{
Analisis Hambatan Pembelajaran \\ Bahasa Indonesia di Sekolah Dasar
}

\author{
Muhamad Alfi Khoiruman \\ Akademi Kelautan Banyuwangi
}

\begin{abstract}
Learning Indonesian in elementary school can help students to get to know themselves, their culture and other cultures, express ideas, participate in society, and discover and use their analytical and imaginative abilities. In the implementation of Indonesian language learning, there are many gaps, so that it is less able to achieve the learning objectives that have been determined optimally. This research was conducted in class 5 SDN Tegalsari 1 Banyuwangi, East Java, Indonesia. The purpose of this study was to determine the obstacles in the process of learning Indonesian in elementary schools. This research uses a case study approach. Data was collected by observing the Indonesian language learning process, interviews, and checking the average test scores of students. The data collected were analyzed using interactive analysis according to Miles and Huberman. The results of the research are 1) Teachers have not used media in the learning process, especially learning Indonesian; 2) The learning carried out is still conventional; 3) Students in learning tend to memorize the subject matter. Through learning innovations that are in accordance with the characteristics of elementary school students, it is expected to be able to create meaningful learning.
\end{abstract}

Keywords: Barriers, Indonesian, language learning, elementary school.

\section{Pendahuluan}

Pendidikan adalah usaha sadar manusia dalam memahami dirinya dan lingkungannya atau usaha manusia dalam memahami interaksi antara makro dan mikro kosmos. Oleh karena itu pendidikan harus mampu menumbuhkan dan menumbuhkan kesadaran akan makna keberadaan manusia bagi lingkungan dan alam sekitarnya (Hude, Febrianti \& Cece, 2019). Seiring dengan kebutuhan masyarakat dalam upaya memenuhi kebutuhan hidup, pendidikan akan terus tumbuh dan berkembang. Pendidikan berfungsi sebagai fasilitator untuk memberikan pemahaman dasar kepada manusia agar dapat produktif dalam mengelola lingkungan sekitar. Pendidikan harus didorong ke arah yang lebih produktif, yaitu menciptakan sesuatu untuk merangsang manusia agar kreatif dan produktif, terutama dalam memenuhi kebutuhan hidup baik fisik maupun non fisik. Sesuai dengan pendapat Sadiman, Rahardjo, Haryono dan Rahardjito (2011) menyatakan bahwa proses pembelajaran harus dirancang secara sistematis dengan memusatkan perhatian pada siswa. Pembelajaran direncanakan berdasarkan kebutuhan dan karakteristik siswa dan diarahkan untuk mengubah perilaku siswa sesuai dengan tujuan yang ingin dicapai. 
Dalam mencapai tujuan pembelajaran diperlukan lingkungan belajar yang kondusif. Menurut Sanjaya (2010, hlm. 162) menyatakan bahwa "proses pembelajaran adalah proses komunikasi. Dalam proses komunikasi selalu melibatkan tiga komponen utama, yaitu komponen pengirim pesan (guru), komponen penerima pesan. (siswa), dan komponen pesan itu sendiri yang biasanya berupa materi pelajaran”. Terkadang dalam proses pembelajaran komunikasi gagal. Artinya materi pelajaran atau pesan yang disampaikan oleh guru tidak dapat diterima siswa secara maksimal, artinya tidak semua materi pelajaran dapat dipahami dengan baik oleh siswa, bahkan siswa yang dirugikan karena penerima pesan salah memahami isi pesan. disampaikan.

Menurut Badan Standar Nasional Pendidikan (2006) tujuan pembelajaran bahasa Indonesia di sekolah dasar bagi siswa adalah untuk mengembangkan kemampuan bahasa Indonesia. Tujuan pembelajaran bahasa Indonesia sesuai dengan keterampilan, kebutuhan dan minat, sedangkan bagi guru untuk mengembangkan potensi bahasa Indonesia siswa, dan lebih mandiri dalam menentukan bahan ajar bahasa yang sesuai dengan kondisi lingkungan sekolah dan kemampuan siswa. Padahal, berdasarkan pengamatan, pembelajaran bahasa Indonesia kurang mampu mendukung pencapaian tujuan pembelajaran bahasa Indonesia. Permasalahannya terletak pada metode yang digunakan dalam pembelajaran, bahan ajar yang digunakan dan penggunaan media pembelajaran. Pemilihan salah satu metode pembelajaran tertentu akan mempengaruhi jenis media pembelajaran yang sesuai, meskipun masih banyak aspek lain yang harus diperhatikan dalam memilih media tersebut. Meski begitu, dapat dikatakan bahwa salah satu fungsi utama media pembelajaran adalah sebagai alat bantu dalam proses pembelajaran yang turut mempengaruhi iklim, kondisi dan lingkungan yang diciptakan oleh guru (Azhar, 2015).

Pembelajaran bahasa Indonesia di sekolah dasar harus memperhatikan cara berpikir siswa dari konkrit ke abstrak. Ciri utama siswa sekolah dasar adalah mereka menampilkan perbedaan individu dalam banyak aspek dan bidang, di antaranya perbedaan kecerdasan, kemampuan kognitif dan bahasa, perkembangan kepribadian dan perkembangan fisik anak. Semakin sadar diri selain memiliki keinginan, perasaan tertentu juga tumbuhnya minat tertentu, kemampuan berpikir masih pada tingkat perspektif dan ketergantungan pada orang dewasa semakin berkurang dan membutuhkan perlindungan orang dewasa yang kurang. Oleh karena itu, setiap guru harus memiliki keterampilan dalam memilih strategi mengajar untuk setiap jenis kegiatan pembelajaran. Dengan demikian, dengan memilih strategi pembelajaran yang tepat pada setiap jenis kegiatan pembelajaran diharapkan pencapaian tujuan pembelajaran dapat tercapai (Laki, 2018). Peran pengajar lebih erat kaitannya dengan keberhasilan siswa, terutama yang berkaitan dengan kemampuan guru dalam menetapkan strategi pembelajaran.

Dunia pendidikan selalu berkembang seiring dengan perkembangan dunia. Begitu juga dengan sarana dan prasarana pendidikan yang lebih memadai dan lebih lengkap. Sehingga pembelajaran dapat dilakukan secara optimal. Demikian juga media yang digunakan dalam proses belajar mengajar semakin kompleks. Perkembangan teknologi akhirnya merambah ke dunia pendidikan. Banyak sekolah sekarang menggunakan teknologi ini untuk memudahkan pembelajaran di sekolah. Teknologi dalam pembelajaran dapat menjadi sarana pembelajaran, metode/media dan sebagai sumber belajar bagi siswa (Rahman, Munawar \& Berman, 2014). 
Sebagai sarana teknologi merupakan alat untuk mempermudah pembelajaran. Sebagai metode/media teknologi sebagai inovator agar pembelajaran menjadi lebih menarik. Sedangkan sebagai sumber teknologi pembelajaran menjadi salah satu penyedia informasi bagi siswa. Diantara sekian banyak teknologi pembelajaran salah satunya adalah multimedia interaktif. Sebagai salah satu media, multimedia interaktif merupakan salah satu teknologi pembelajaran yang memiliki keunggulan yang cukup baik untuk pelaksanaan pembelajaran (Lia, 2015).

Penggunaan media pembelajaran yang tepat diharapkan dapat merangsang pikiran, perhatian dan minat siswa sehingga proses pembelajaran dapat berjalan dengan lancar dan menyenangkan. Hal ini juga dikemukakan oleh Soewarno, Hasmiana dan Faiza (2016) yang menyatakan bahwa "tidak semua siswa memiliki kemampuan yang sama dan media harus efektif digunakan jika tidak bergantung pada kemampuan anak". Penggunaan media komunikasi tidak hanya dapat mempermudah dan mengefektifkan proses pembelajaran, tetapi juga dapat membuat proses pembelajaran menjadi lebih menarik. Di era globalisasi ini, program pembelajaran juga nampaknya belum mampu memberikan hasil yang memuaskan. Hal ini terlihat pada saat proses pembelajaran berlangsung, suasana kelas terkesan tegang dan membosankan. Guru sibuk menyampaikan materi tanpa ingin tahu pemahaman siswa atau tidak. Kebanyakan guru dalam mengajar selalu monoton atau tidak melakukan variasi. Banyak guru yang buta teknologi kurang mampu menggunakan media dalam proses pembelajaran. Hal ini sejalan dengan penelitian Garcia, Quiroz, Santos, Gonzalez dan Fernanz (2007, hlm. 615) yang menyatakan "tumbuhnya perhatian para guru untuk meningkatkan teori kelas mereka bersama dengan revolusi dalam konten dan metode yang dibawa oleh teknologi informasi baru menggabungkan untuk menawarkan siswa bentuk belajar yang lebih menarik, efisien dan menyenangkan". Lebih lanjut Yuen \& Liu (2011) menyatakan bahwa "model kognitif dalam interactive multimedia authoring (IMA) mempengaruhi kognisi siswa dalam pemrograman berorientasi objek". Penelitian di atas sebagai salah satu manfaat penggunaan media yang berorientasi pada cara berpikir konkrit ke abstrak.

Pembelajaran bahasa Indonesia di sekolah dasar perlu dioptimalkan. Menurut Resmini, Churiyah dan Sundori (2006, hlm. 49) menyatakan "bahasa adalah alat komunikasi, melalui bahasa manusia dapat saling berkomunikasi, berbagi pengalaman, saling belajar, dan meningkatkan kemampuan intelektual". Oleh karena itu, belajar bahasa pada hakikatnya adalah belajar komunikasi. Pembelajaran diarahkan untuk meningkatkan keterampilan belajar dalam berkomunikasi, baik lisan maupun tulisan. Menurut Izzan (2010, p.24) bahwa "pengajaran bahasa melibatkan tiga disiplin ilmu yaitu linguistik, psikologi, dan pendidikan". Linguistik memberikan informasi tentang bahasa pada umumnya dan bahasa tertentu. Psikologi menggambarkan bagaimana orang mempelajari sesuatu, dalam ilmu pendidikan memungkinkan seseorang untuk mengumpulkan semua informasi ke dalam cara atau metode yang cocok untuk digunakan di kelas sehingga memudahkan proses belajar dan mengajar bahasa oleh siswa. Berdasarkan fenomena dan permasalahan dalam pembelajaran bahasa Indonesia di sekolah dasar di atas, penelitian ini dapat merumuskan kendala dalam pembelajaran bahasa Indonesia di 
sekolah dasar. Tujuan dari penelitian ini adalah untuk mengetahui kendala-kendala pembelajaran bahasa Indonesia di sekolah dasar.

\section{Metodologi \\ Tujuan Penelitian}

Tujuan dari penelitian ini adalah untuk mengetahui kendala dalam pembelajaran bahasa Indonesia di sekolah dasar. Penelitian ini menggunakan pendekatan studi kasus. Secara umum, tujuan dari penelitian ini adalah untuk menggali hambatan dalam proses pembelajaran bahasa Indonesia di sekolah dasar. Sedangkan secara khusus, tujuan penelitian ini adalah: 1) mengetahui bagaimana proses pembelajaran bahasa Indonesia terjadi di kelas; 2) mengetahui strategi, metode, atau model yang digunakan guru dalam mengajar di kelas; 3) mengetahui bagaimana respon dan antusias siswa dalam mengikuti pembelajaran di kelas; dan 4) mengetahui hambatan atau kendala yang dialami guru dan siswa dalam pembelajaran bahasa Indonesia.

\section{Sampel dan Pengumpulan Data}

Penelitian ini dilaksanakan di SDN Tegalsari 1 Banyuwangi Jawa Timur, Indonesia. Kegiatan dalam penelitian meliputi persiapan penelitian, pengumpulan dan pengolahan data, serta penyusunan laporan penelitian. Penelitian ini menggunakan pendekatan kualitatif deskriptif. Teknik pengumpulan data yang digunakan dalam penelitian ini adalah teknik observasi partisipatif, wawancara mendalam, dan analisis dokumen dengan menggunakan instrumen sebagai pedoman observasi, wawancara, dan analisis dokumen. Observasi yang digunakan dalam penelitian ini adalah observasi langsung, yang disebut observasi langsung yang berperan pasif. Pengamatan ini dilakukan secara terencana dan terkendali. Peneliti melakukan observasi terhadap kegiatan pembelajaran. Kegiatan observasi ini juga dilengkapi dengan blanko, isian check list, dan daftar lain yang telah disiapkan. Wawancara dilakukan secara terstruktur. Wawancara dilakukan dengan guru dan beberapa siswa kelas 5. Analisis dokumen dilakukan selama kegiatan penelitian. Dokumen yang digunakan dalam penelitian ini antara lain: silabus, rencana pelaksanaan pembelajaran, kriteria ketuntasan minimal, dan daftar nilai tes bahasa Indonesia siswa. Instrumen yang digunakan dalam pengumpulan data adalah instrumen yang telah divalidasi. Data yang terkumpul divalidasi menggunakan teknik triangulasi untuk menentukan relevansi dan kecocokan data. Teknik analisis yang digunakan dalam penelitian ini adalah teknik analisis yang menggunakan model analisis interaktif.

\section{Analisis data}

Teknik analisis yang digunakan dalam penelitian ini adalah teknik analisis yang menggunakan model analisis interaktif. Menurut Miles dan Huberman (2009) menyatakan bahwa "model analisis interaktif memiliki empat komponen, yaitu: (1) pengumpulan data, (2) reduksi data, (2) penyajian data, dan (3) penarikan kesimpulan (verifikasi)". Keabsahan data dalam penelitian ini diperoleh melalui triangulasi teknik, dan peer review melalui diskusi. Triangulasi teknis diperoleh dengan membandingkan data hasil observasi pembelajaran, wawancara mendalam, dan analisis dokumen yang dilakukan peneliti sehingga ditemukan 
kesamaan dan kebenaran data yang diambil. Peer Examination dilakukan dengan melakukan diskusi dengan rekan sejawat yang dianggap memiliki pengetahuan tentang masalah yang diteliti. Jadi data yang diperoleh adalah data yang sudah terbukti kebenarannya.

\section{Pembahasan / Hasil}

Berdasarkan observasi yang dilakukan peneliti di kelas 5 ditemukan bahwa masih banyak permasalahan dalam pembelajaran bahasa Indonesia. Wawancara dengan guru kelas 5 dilakukan untuk mengetahui berbagai kendala yang terjadi dalam pembelajaran bahasa Indonesia. Beberapa pertanyaan yang diajukan dalam wawancara antara lain: 1) Bagaimana Anda mengajarkan materi dalam bahasa Indonesia kepada siswa? Hasilnya "Saya mengajarkan materi Bahasa Indonesia sesuai dengan buku pegangan yang ada. Materi yang saya rekam untuk siswa juga sesuai dengan buku pegangan yang digunakan"; 2) Metode, model, strategi atau media apa yang Anda gunakan untuk menjelaskan materi dalam bahasa Indonesia? Hasilnya "Dalam penyampaian materi saya jarang menggunakan metode, model, strategi, atau media. Saya lebih sering menjelaskan materi dengan ceramah dan tanya jawab"; 3) Bagaimana kondisi pembelajaran yang terjadi saat Anda menyampaikan materi bahasa Indonesia di kelas? Hasilnya adalah "Pembelajaran berjalan dengan baik, siswa mendengarkan dan mencatat apa yang saya tulis di papan tulis"; 4) Apa saja kendala atau kendala yang anda alami saat belajar bahasa Indonesia? Hasilnya adalah "Kendala yang saya alami dalam pembelajaran bahasa Indonesia antara lain saya tidak mengerti dan memahami cara penggunaan media pembelajaran khususnya media berbasis IT. Keterbatasan itulah yang menyebabkan pembelajaran hanya menggunakan metode konvensional yaitu ceramah dan tanya jawab. dan jawaban.Selain itu, saya berasumsi bahwa materi dalam bahasa Indonesia bukanlah materi yang sulit, jadi saya lebih fokus pada mata pelajaran lain yang mengandung materi yang sulit, seperti matematika dan IPA". Berdasarkan hasil wawancara mendalam yang dilakukan oleh peneliti dengan guru kelas 5 diketahui banyak kendala yang dialami guru dalam pembelajaran bahasa Indonesia di kelas 5 diantaranya : 1) Guru kurang dapat menggunakan fasilitas penunjang pembelajaran berbasis IT untuk pembelajaran bahasa Indonesia, hal tersebut dikarenakan guru hanya berorientasi pada pencapaian setiap kompetensi dasar dengan keterbatasan waktu yang ada; 2) Masih adanya anggapan guru bahwa pelajaran bahasa Indonesia ns adalah pelajaran yang mudah sehingga tidak perlu dijadikan prioritas dalam penyampaian pembelajaran di kelas; 3) Guru lebih cenderung fokus pada mata pelajaran lain. Sehingga dalam penyampaian materi pelajaran bahasa Indonesia, guru hanya menyampaikan pokok-pokok dan menyampaikannya secara sekilas. Tentu hal ini mengakibatkan pemahaman dan prestasi siswa pada pelajaran bahasa Indonesia rendah. Wawancara yang dilakukan pada siswa kelas 5 juga dilakukan untuk mengetahui berbagai kendala yang dialami siswa dalam belajar bahasa Indonesia. Beberapa pertanyaan yang diajukan dalam wawancara tersebut, antara lain: 1) Bagaimana pendapat Anda tentang gaya mengajar guru di kelas? Hasilnya adalah "Guru dalam mengajar sangat monoton, guru hanya menjelaskan materi dan kita hanya disuruh mendengarkan dan mencatat apa yang dikatakan guru"; 2) Bagaimana perasaan Anda ketika guru mengajar di kelas? Hasilnya "Kami merasa pembelajaran sangat membosankan karena guru 
tidak berinovasi dalam pembelajaran"; 3) Metode, model, strategi atau media apa yang digunakan guru dalam menjelaskan materi dalam bahasa Indonesia? Hasilnya adalah "Guru jarang menggunakan metode, model, strategi, atau media dalam pembelajaran khususnya bahasa Indonesia. Guru hanya ceramah dan tanya jawab"; 4) Apa saja kendala atau kendala yang anda hadapi dalam belajar bahasa Indonesia? Hasilnya adalah "Pembelajaran Bahasa Indonesia yang dilakukan di dalam kelas sangat membosankan, karena dalam pembelajaran seperti itu siswa hanya disuruh mendengarkan dan mencatat apa yang disampaikan guru. Selain itu, guru tidak pernah menggunakan media dalam pembelajaran. pembelajaran khususnya bahasa Indonesia, sehingga pembelajaran yang berlangsung kurang menarik bagi kami.Saat menjelaskan materi dalam bahasa Indonesia, guru tidak mampu menjelaskan materi secara lengkap dan detail, sehingga hal ini menyebabkan kami sering tidak paham dan kurang memahami materi. materi yang disampaikan oleh guru Berdasarkan hasil wawancara yang dilakukan peneliti dengan siswa kelas V diketahui bahwa: 1) Pembelajaran yang dilakukan oleh guru kelas 5 terlihat membosankan karena dalam pembelajaran siswa hanya mendengarkan dan menerima apa yang disampaikan oleh guru; 2) Siswa merasa belajar bahasa Indonesia sulit karena kurangnya guru dalam menjelaskan materi dalam bahasa Indonesia dengan baik dan mendalam; 3) Guru kurang inovatif karena dalam deli Verifikasi materi hanya menggunakan metode ceramah dan tanya jawab. Guru belum bisa menggunakan metode, model, atau media pembelajaran.

Berdasarkan analisis dokumen berupa silabus, RPP, KKM, dan daftar nilai ujian bahasa Indonesia yang telah dilakukan, diperoleh hasil "beberapa dokumen seperti silabus, RPP, dan KKM, guru cari saja di internet lalu print sehingga tidak ditemukan dokumen yang benar-benar dibuat oleh guru sendiri. Selain itu, banyak daftar nilai bahasa Indonesia yang belum diisi atau diisi dan banyak juga nilai ulangan yang kosong. Tentu saja hal ini menjadi menjadi masalah karena menunjukkan bahwa Bahasa Indonesia tidak menjadi prioritas dalam menyampaikan pelajaran sehingga guru jarang memberikan tugas kepada siswa dan jarang mengadakan ulangan. KKM yang ditentukan”. Beberapa kendala yang peneliti temukan dapat dikemukakan bahwa kendala yang terjadi disebabkan oleh beberapa faktor, baik faktor yang disebabkan oleh guru maupun siswa. Sehingga hal ini berdampak pada rendahnya nilai siswa. Hal ini dapat dilihat pada tabel dan diagram berikut ini:

Tabel 1. Hasil Hasil Tes Bahasa Indonesia Siswa Kelas 5

\begin{tabular}{|c|c|c|}
\hline Nomer Siswa & Skor Diperoleh & Skor \\
\hline 1 & 40 & 80,0 \\
\hline 2 & 32 & 64,0 \\
\hline 3 & 24 & 48,0 \\
\hline 4 & 25 & 50,0 \\
\hline 5 & 31 & 62,0 \\
\hline 6 & 35 & 70,0 \\
\hline 7 & 32 & 64,0 \\
\hline 8 & 32 & 64,0 \\
\hline
\end{tabular}




\begin{tabular}{|c|c|c|}
\hline 9 & 44 & 88,0 \\
\hline 10 & 38 & 76,0 \\
\hline 11 & 26 & 52,0 \\
\hline 12 & 30 & 60,0 \\
\hline 13 & 30 & 60,0 \\
\hline 14 & 30 & 60,0 \\
\hline 15 & 22 & 44,0 \\
\hline 16 & 23 & 46,0 \\
\hline 17 & 45 & 90,0 \\
\hline 18 & 22 & 44,0 \\
\hline 19 & 24 & 48,0 \\
\hline 20 & 24 & 48,0 \\
\hline 21 & 44 & 88,0 \\
\hline 22 & 22 & 44,0 \\
\hline 23 & 26 & 52,0 \\
\hline \multicolumn{2}{|c|}{ Total } & 1394,0 \\
\hline \multicolumn{2}{|c|}{ Rata-rata } \\
\hline
\end{tabular}

Berdasarkan hasil nilai tes dapat disajikan pada diagram di bawah ini:

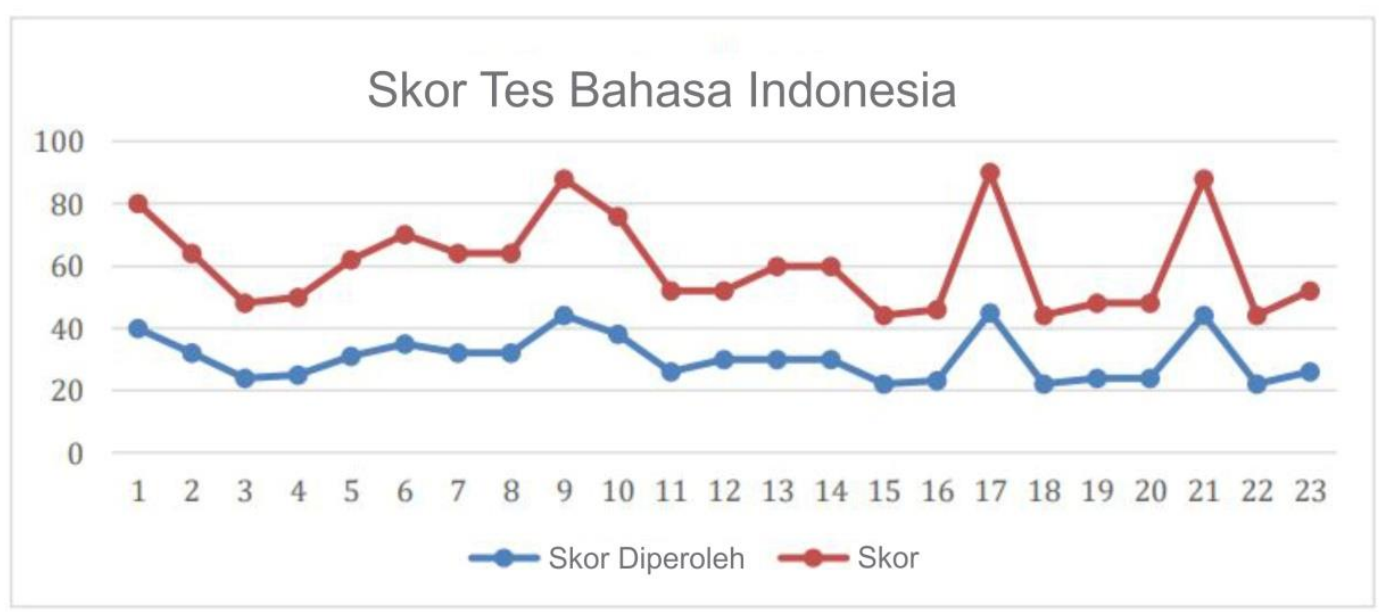

Gambar 1. Diagram Kelas nilai tes Bahasa Indonesia siswa kelas 55

Berdasarkan tabel dan diagram di atas, dapat disimpulkan bahwa rata-rata hasil nilai tes Bahasa Indonesia siswa kelas 5 adalah 60,6 dengan rata-rata ketuntasan siswa 26,08\% dan ratarata ketuntasan siswa $73,91 \%$. Hal ini membuktikan bahwa tingkat pemahaman siswa terhadap materi bahasa Indonesia yang disampaikan oleh guru sangat rendah. Dengan demikian, terdapat kesesuaian antara hasil wawancara yang dilakukan dengan guru, siswa, dan hasil tes siswa kelas 5 bahasa Indonesia.

\section{Diskusi dan kesimpulan}

Penelitian ini difokuskan untuk mendeskripsikan hambatan-hambatan dalam pembelajaran bahasa Indonesia di kelas 5 SD. Materi dalam bahasa Indonesia menjadi kurang optimal karena guru dalam menyampaikan materi kepada siswa hanya menggunakan metode ceramah dan 
bercerita. Siswa hanya mendengarkan penjelasan dari guru dan tidak terlihat aktif di kelas, sehingga pembelajaran yang berlangsung masih berpusat pada guru. Temuan ini menunjukkan bahwa pemilihan metode pengajaran oleh guru masih belum tepat. Hal ini sejalan dengan penelitian yang dilakukan oleh Ixganda dan Suwahyo (2015) yang menyatakan bahwa "metode mengajar guru masih kurang baik dan kurang tepat". Hal ini dapat dilihat pada gambar di bawah ini:

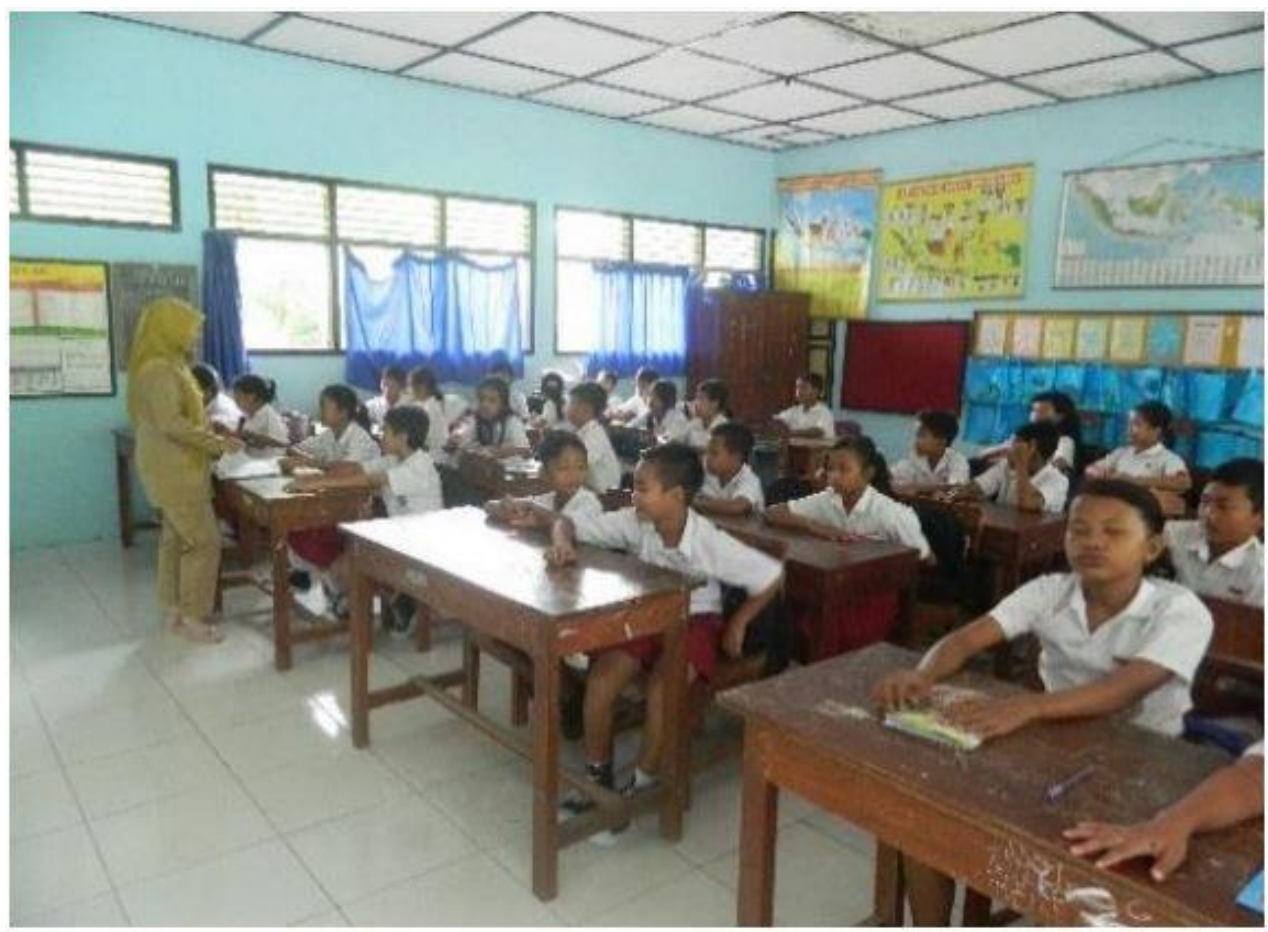

Gambar 2. Pembelajaran Bahasa Indonesia di Kelas 5

Hal ini sejalan dengan Wahyuhastufi (2016) yang menyatakan bahwa "guru mengalami kendala dalam penggunaan media pembelajaran yang masih kurang tersedianya dan penerapan metode pembelajaran yang kurang bervariasi". Masalah lain yang ditemukan adalah kesulitan yang dialami guru dalam menyampaikan materi pelajaran. Hal ini dapat dibuktikan dalam kegiatan pembelajaran yang berlangsung pada materi pantun. Dalam pembelajaran yang sedang berlangsung, terlihat guru tidak menggunakan media pembelajaran apapun dalam menyampaikan pantun kepada siswa kelas 5 SD. Pembelajaran yang berlangsung hanya didominasi dengan metode ceramah dan bercerita sehingga menyebabkan siswa terlihat bosan dan akhirnya materi yang disampaikan tidak dapat diterima dengan baik oleh siswa.

Selain itu, dalam menyampaikan materi tentang pantun, guru hanya menggunakan buku pelajaran, sehingga pembelajaran terkesan kurang mengasyikkan. Hal ini tidak sejalan dengan penelitian Ruhyana (2016, hlm. 115) yang menyatakan bahwa "pembelajaran yang dapat mengembangkan penalaran proporsional bukanlah pembelajaran klasikal tetapi pembelajaran penuh kegiatan yang melibatkan semua siswa untuk ambil bagian". Selain itu, terkait kegiatan belajar mengajar yang berlangsung masih pasif dan masih berorientasi pada teacher centered. 
Pembelajaran yang berorientasi pada guru menyebabkan tidak adanya keterlibatan siswa dalam proses pembelajaran yang berlangsung. Hal ini sejalan dengan pendapat Muhana (2004, hlm. 60) yang menyatakan bahwa "sejauh ini siswa lebih banyak belajar menghafal daripada berlatih". Sehingga tidak ditemukan kegiatan diskusi kelompok atau kerja kelompok selama proses pembelajaran. Hal ini didukung oleh penelitian yang dilakukan oleh Suryani (2010, hlm. 33) yang menyatakan "kondisi dimana anak dengan kemampuan kecerdasan rata-rata atau di atas rata-rata, tetapi mengalami kecacatan atau kegagalan dalam belajar terkait dengan hambatan dalam proses belajar". Diperkuat oleh Purnami \& Susiati (2015, hlm. 18) yang menyatakan "kesulitan belajar siswa tidak selalu disebabkan oleh kecerdasan yang rendah, tetapi dapat juga disebabkan oleh faktor lain di luar kecerdasan. Dengan demikian, IQ yang tinggi belum tentu menjamin keberhasilan belajar".

Guru dituntut untuk dapat menyampaikan materi bahasa Indonesia dengan waktu yang terbatas dan materi yang cukup banyak. Selain itu, penggunaan metode pembelajaran dalam pembelajaran bahasa Indonesia juga belum bervariasi. Selain faktor dari guru juga ada faktor dari siswa yaitu tidak semua siswa siap mengikuti pembelajaran dan siswa kurang antusias terhadap mata pelajaran bahasa Indonesia. Berdasarkan hasil nilai tes siswa pada mata pelajaran bahasa Indonesia tersebut, perlu adanya solusi untuk dapat mengatasi berbagai permasalahan yang ada. Solusinya, pembelajaran yang dilakukan guru di kelas perlu didukung dengan media atau alat peraga yang sesuai. Salah satu jenis media yang dapat digunakan adalah dengan menggunakan multimedia pembelajaran interaktif yaitu media yang memiliki media yang lengkap seperti suara, teks, gambar, animasi, video yang dapat menambah dan merangsang minat dan semangat siswa dalam belajar. Penggunaan multimedia pembelajaran interaktif dalam proses pembelajaran dapat dijadikan sebagai solusi untuk mengatasi berbagai kendala yang terjadi. Dalam membuat program multimedia pembelajaran interaktif yang memiliki banyak fitur dan konten sangat dibutuhkan agar multimedia interaktif yang dibuat dapat menarik minat dan perhatian siswa. Selain itu, program juga harus mudah dioperasikan agar siswa tidak mengalami kesulitan dalam menggunakannya. Salah satu program yang dapat digunakan adalah dengan menggunakan Adobe Flash. Program ini memiliki keistimewaan karena dapat menyajikan berbagai media yaitu suara, teks, animasi, gambar, dan video secara lebih mudah, dapat dirancang sesuai dengan kebutuhan sekolah karena program ini memiliki banyak fitur dan konten yang dapat digunakan untuk merancang multimedia pembelajaran interaktif. Hal ini juga diperkuat oleh penelitian yang dilakukan oleh Nurdiyanti \& Suryanto (2010) yang menyatakan bahwa "melalui penggunaan media mampu meningkatkan daya tarik siswa untuk berpartisipasi dalam pembelajaran". Berdasarkan hasil penelitian yang telah dilakukan, dapat disimpulkan bahwa terdapat beberapa kendala dalam pembelajaran bahasa Indonesia di sekolah dasar. Kendala yang terjadi disebabkan oleh beberapa faktor yaitu faktor dari guru dan siswa. Hambatan yang dialami guru dalam pembelajaran bahasa Indonesia antara lain: 1) Guru kurang mampu menggunakan fasilitas penunjang pembelajaran berbasis IT untuk pembelajaran bahasa Indonesia; 2) Masih adanya anggapan dari guru bahwa pembelajaran bahasa Indonesia adalah mata pelajaran yang mudah; 3) Guru lebih cenderung fokus pada mata pelajaran lain. Selain itu ada juga faktor yang berasal dari 
siswa, antara lain: 1) Pembelajaran yang dilakukan guru terlihat membosankan; 2) Siswa merasa bahwa belajar bahasa Indonesia adalah mata pelajaran yang sulit; 3) Guru kurang inovatif dalam pembelajaran. Hasil nilai tes siswa Indonesia juga menunjukkan hal yang sama. Banyak siswa yang belum mampu mencapai KKM yang telah ditetapkan. Rata-rata ketuntasan siswa adalah $26,08 \%$ dan rata-rata ketuntasan siswa adalah $73,91 \%$. Oleh karena itu diperlukan suatu inovasi dalam pembelajaran agar pembelajaran yang berlangsung lebih menyenangkan, menginspirasi siswa, dapat meningkatkan hasil belajar siswa.

\section{Saran}

Berdasarkan hasil penelitian, dapat dikemukakan saran sebagai berikut: Masalah yang ditemukan dapat dikembangkan lebih lanjut oleh peneliti untuk lebih memperdalam penelitian sejenis.

1. Masalah yang ditemukan dapat menjadi pendorong bagi guru untuk mau belajar dan memperdalam ilmu tentang mengajar dan berkreasi

2. Suasana belajar yang menyenangkan, mengaktifkan siswa, dan bermakna. Hasil penelitian dapat menjadi stimulus bagi guru untuk lebih meningkatkan keterampilan, kemahiran dan kualitas pengajaran.

3. Hasil penelitian dapat digunakan untuk mendorong peneliti lain untuk melakukan penelitian serupa di masa yang akan datang, dengan lebih banyak lagi

4. Variabel dan hasil penelitian yang lengkap dan terperinci.

\section{Daftar Pustaka}

Azhar, A. (2017). Media pembelajaran [Learning media]. Jakarta, Indonesia: Rajagrafindo.

Badan Standar Nasional Pendidikan. (2006). Permendiknas RI No. 22 Tahun 2006 tentang Standar Isi untuk Satuan Pendidikan Dasar dan Menengah [Indonesian Minister of Education Regulation No. 22 of 2006 concerning Content Standards for Primary and Secondary Education Units]. Jakarta, Indonesia.

Garcia, R. R., Quiroz, J. S., Santos, R. G., Gonzalez, S. M., \& Fernanz, S. M. (2007). Interactive multimedia animation with macromedia flash in descriptive geometry teaching. Journal Computers and Education, 49(3), 615-639.

Hude, D., Febrianti, N. A., \& Cece. (2019). Penguatan pendidikan karakter melalui kearifan lokal berbasis al-quran (implementasi di SMAN Kabupaten Purwakarta) [Strengthening character education through local wisdom based on al-quran (implemented at SMAN Purwakarta Regency)]. Journal of Islamic Education, 1(2), 335-352.

Ixganda, O., \& Suwahyo. (2015). Analisis deskriptif faktor penyebab kesulitan belajar pada mata pelajaran chasis dan pemindah daya siswa kelas XI program keahlian teknik kendaraan ringan [Descriptive analysis of the causes of learning difficulties in chassis and power transfer subjects in class XI light vehicle engineering program]. Journal of Mechanical Engineering Education/Jurnal Pendidikan Teknik Mesin, 15(2), 103-108. 
Izzan, A. (2010). Metodologi pembelajaran bahasa inggris [English learning methodology]. Bandung, Indonesia:

Humoniora. Laki, R. (2018). Strategi pembelajaran bahasa indonesia di era kurikulum tingkat satuan pendidikan (KTSP) [Indonesian language learning strategies in the era of education unit level curriculum (EULC)]. Journal of Education and Learning/Jurnal Pendidikan dan Pembelajaran, 1(1), 23-29.

Lia, L. (2015). Multimedia interaktif sebagai salah satu alternatif pembelajaran dalam bidang pendidikan sains [Interactive multimedia as an alternative learning in the field of science education]. Journal of Innovation and Physics Learning/Jurnal Inovasi dan Pembelajaran Fisika, 2(2), 132-140.

Milles, Mattew B., \& Huberman, A. (2009). Analisis data kualitatif [Qualitative data analysis]. Jakarta, Indonesia: Universitas Indonesia Press.

Muhana, G. (2004). Pengajaran literasi dan penilaian portofolio dalam konteks pembelajaran menulis di SD [Literacy teaching and portfolio assessment in the context of writing learning in elementary schools]. Journal of Education/Jurnal Ilmu Pendidikan, 11(1), 59-70.

Nurdiyanti, E., \& Edy S. (2010). Pembelajaran literasi mata pelajaran bahasa indonesia pada siswa kelas V sekolah dasar [Literacy learning indonesian language subjects in class $\mathrm{V}$ students of elementary schools]. Paedagogia, 13(2), 115- 128.

Purnami, I., \& Susiati, Y. T. (2015). Faktor-faktor kesulitan belajar dalam mengikuti mata pelajaran keterampilan tata busana siswa SMPN 1 Suruh Semarang [Factors of learning difficulties in following subjects in clothing design skills in SMPN 1 Suruh Semarang]. Journal of Family/Jurnal Keluarga, 1(1), 14-19.

Rahman, S., Wahid, M., \& Berman, Ega T. (2014). Pemanfaatan media pembelajaran berbasis website pada proses pembelajaran produktif di SMK [Website-based learning media utilization in the productive learning process in vocational schools]. Journal of Mechanical Engineering Education, 1(1), 137-145.

Resmini, N., Churiyah, Y., \& Sundori, N. (2006). Membaca dan menulis di SD: teori dan pengajarannya [Reading and writing in elementary school: theory and teaching]. Bandung, Indonesia: UPI Press.

Ruhyana. (2016). Analisis kesulitan siswa dalam pemecahan masalah matematika [Analysis of student difficulties in mathematical problem solving]. Journal Computech \& Bisnis, 10(2), 106-118.

Sadiman, A. S., Rahardjo, S., Haryono, A., \& Rahardjito. (2011). Media pendidikan, pengertian, pengembangan dan pemanfaatannya [Education media, understanding, development and utilization]. Jakarta, Indonesia: PT Grafindo Persada. Sanjaya, W. (2010). Penelitian tindakan kelas [Classroom action research]. Jakarta, Indonesia: PT. Prenada Media.

Soewarno, Hasmiana, \& Faiza. (2016). Kendala-kendala yang dihadapi guru dalam memanfaatkan media berbasis komputer di SD Negeri 10 Banda Aceh [Constraints 
faced by teachers in utilizing computer-based media in SD Negeri 10 Banda Aceh]. Journal of Basic Charm/Jurnal Pesona Dasar, 2(4), 28-39.

Suryani, \& Yulinda, E. (2010). Kesulitan belajar [Difficulty learning]. Journal of Magistra Research/Jurnal Penelitian Magistra, 22(73), 33-47.

Wahyuhastufi, A. (2016). Identification of obstacles in learning teacher in class III A school inclusion SDN Giwangan Yogyakarta. Journal of Primary School Teacher Education /Jurnal Pendidikan Guru Sekolah Dasar, 2(5), 81-86.

Yuen, T., \& Liu, M. (2011). Journal of A cognitive model of how interactive multimedia authoring facilities conceptual understanding of object-oriented programming in novices. Journal of Interactive Learning, 22(3), 329-356. 